\title{
Community Empowerment with Training in the Making of Spice Tea Beverages in Banjaragung Village, Tuban District
}

\author{
Author \\ Abdul Khafid Maulana (Orcid ID. 0000-0003-1534-1185), \\ Muhammad Yusuf (Orcid ID. 0000-0002-2168-3176), \\ Hendra Suwardana (Orcid ID. 0000-0002-9856-8838), \\ Miftachul Munir (Orcid ID. 0000-0003-3329-9515), \\ Fiki Andriyan (Orcid ID. 0000-0001-8133-5563)

\section{Correspondence} \\ University of PGRI Ronggolawe Tuban, Jawa Timur, Indonesia, \\ abdulkhafidmaulanan@gmail.com, ucupabubakar@gmail.com
}

\begin{abstract}
:
Community Service is one of the Tri dharmas of Higher Education to be one of the accesses to achieve this vision. The community in Banjaragung Village was chosen as a partner to introduce Health Tea drinks made from pure spices. Through this activity, the author hopes to be able to carry out the mission to realize the learning process in the field of creative economic entrepreneurship with qualities that are relevant to the needs of today's society. Spices and especially sappan wood in Banjaragung Village have not been processed properly and lacked innovation. Considering that today's society needs drinks and food that can increase the body's immune system with spices, community service is made to make training to process secang wood and spices such as red ginger, lemongrass, cinnamon and tea leaves into products that are quickly consumed. By making health tea bags. Secang wood plant or the Latin nameCaesalpinia sappan is one type of spice that can be used for its woody stems or fruit. The components of bioactive compounds contained inwood, namely brazilian, brazilein, 3'-O-methyl braziline, sappansappan, chalcone, sappancalchone are known as antioxidants. Research on sappan wood as an antioxidant and can be used as a natural dye has been a lot. The counseling carried out is expected to provide insight to the community in Banjaragung Village about how to make Health Tea drinks so that they can help improve the economic level of the community.
\end{abstract}

Keywords: Spices, Antioxidants, Health Tea Bags, Banjaragung Village. 


\section{Introduction}

Data on the potential of villages and hamlets describe the potentials that exist in them, consisting of the potential of natural resources and human resources that can be used as development managers. To determine the superior and competitive character of the village or hamlet and increase village or hamlet investment. Banjaragung Village, Rengel District, is one of the villages in Tuban Regency. The distance from Banjaragung Village to Tuban Regency is $24 \mathrm{KM}$, which can be reached in about 40 minutes. Topographically, Banjaragung Village, Rengel District, includes a medium plain, which is about $250 \mathrm{~m}$ above sea level. Banjaragung Village, Rengel District, has an area of $186.186 \mathrm{Ha}$. Banjaragung Village has good potential in agriculture, it can be seen that the majority of the population of Banjaragung Village make a living as farmers with an agricultural land area of about 100 hectares. The business units in Banjaragung Village include agriculture, farmers in Banjaragung Village are 30-50 years old, with the most education level only graduating from elementary school, the land managed by farmers is partly their own and partly rented. meet basic needs and some are sold without processing, farmers in Banjaragung Village still use traditional techniques in farming. In addition to relying on agricultural products, Banjaragung Village has an advantage, namely the growth of secang wood trees in the yard or fields that can be utilized. Farmers use sappan wood to sell in the market or to the PKK group in Banjaragung Village. Unpredictable weather and frequent crop failures due to pests in the fields make some farmers look for other sources of income to earn other income, including farmers who sell sappan wood. Besides sappan wood, there are also spices such as ginger, turmeric, lemongrass. . These spices have several benefits, one of which is to increase the work of the body's immune system to fight various types of bacteria and viruses.

Until now, Indonesia is still in a Covid-19 pandemic condition as well as Tuban, although currently Tuban is in a Level 2 PPKM condition, but the community must also maintain immunity so as not to contract the covid-19 virus, to maintain the body's immunity, people can consume spices. local spices in Tuban, Spices in Tuban need special attention because until now these raw materials have not been processed optimally and are only sold as kitchen spices, eventhough when viewed from the health aspect these spices have many benefits, namely Boost immunity and cure degenerative diseases.Health Tea as a herbal beverage product that is affordable by the general public and has the aim of empowering rural communities who still do not find work.

Secang wood or the Latin name Caesalpinia sappan is one type of spice that is used for its wood or fruit as spices. Secang wood is a type of plant that can thrive in Southeast Asia, including Indonesia and especially in Banjaragung Tuban, Secang plants are often found in the southern Tuban area in the mountains and farmers' fields. Secang plants include thorny tree species with small leaves, the sappan fruit at a glance is similar to Chinese petai which is greenish when young and will turn brown when ripe. In addition, there are yellow-orange flowers on the shoots, the useful parts of the sappan wood are the stems and the fruit, but this time in making sappan wood powder we focus on the stem. Secang wood contains terpenoid compounds, very high phenols, contains high flavonoids, does not contain steroids or tannins. Secang wood extract contains total phenol levels equivalent to EGC $849.11 \mathrm{~g} / \mathrm{mg}$ and ECG equivalent to $825.11 \mathrm{~g} / \mathrm{mg}$, also has high antioxidant activity, namely $80.46-89.13 \%$, but lower than EGC and ECG (Wahyu Widowati in JKM Vol.11 No.1 July 2011:23-31). The journal proves that sappan wood is one of the plants that is rich in benefits, especially for treatment, one of which is that it can cure degenerative diseases or chronic diseases which are often caused by oxidative stress triggered by free radicals.

Secang wood also contains active ingredients that are believed to be able to treat various diseases such as diabetes, skin diseases, diarrhea, to dysentery. The benefits of sappan wood based on several studies are that it can increase the immune system so that it can improve the body's system. Examples are bacillus subtilis disease or vomiting vomiting, (causing skin disease). Salmonella Typhi (Causing typhus), andE. coli(causing diarrhea andalso general indigestion). Based on existing research, sappan wood can be anti-inflammatory and increase the body's immune system. Among 130 herbal medicines tested, sappan wood is an ingredient in herbal medicines that can prevent the inhibition of the activity of hyaluronidase, a genetically designed protein that can cause inflammation. In addition,Brazilian compounds in Brazil are able to protect and maintain healthy liver function. (Aprinda Puji in Hello Sehat, 2021). Until now, Indonesia is still in a state of the Covid-19 Pandemic. On April 9, 2020, Tuban Regency was included in the red zone area category. After it was discovered that a Tuban resident was confirmed positive for Covid-19 (reported from https://In.tuban.go.id/covid19), currently as of 
September 9, Tuban is still declared PPKM level 1, in which the community must maintain body immunity. One of the benefits of sappan wood can also increase immunity, this is very important, because until now sappan wood, especially in the Tuban area, is rarely considered and maximized in its processing.

All raw materials for Health Tea contain ingredients that are beneficial to health, first, Secang wood is an herbal plant that has many benefits for the health of the body. (According to Inten Esti Pratiwi 2021), secang wood extract is believed to treat sore throats. This is because sappan wood extract can inhibit the growth of bacteria Strep Coccus Alpha that causes sore throat. The second is red ginger, red ginger contains a lot of vitamin $\mathrm{C}$ and magnesium, this content helps the body to strengthen the immune system. In addition, ginger can also ward off infections and viruses because ginger also contains gingerol which is believed to inhibit bacterial infections, red ginger also contains high antioxidants that function to prevent free radicals that can cause damage to body cells. The third is lemongrass, lemongrass is a plant that has benefits for reducing fever, preventing flu and nasal congestion and lemongrass can also overcome depression, control pressure and reduce bad cholesterol in the body. Fourth is turmeric, turmeric is an herbal plant that can prevent the covid-19 virus. Based on the news and research and development of industrial plants volume 19 No. 2 issued by the Ministry of Agriculture, turmeric is an herbal plant that is useful as traditional medicine, turmeric contains curcumin and essential oils which have antioxidant, antitumor androles anticancer, turmeric also contains antiinflammatory and antioxidants in it can maximize the body's resistance from various diseases including the covid-19 virus. (In Lusiana Mustinda 2020). Fifth is cinnamon, cinnamon is also a plant that is rich in antioxidants and anti- inflammatory, this content can be useful for the body to increase the immune system and can relieve inflammation and release excessive fluid deposits in the body.

Secang wood farmers sell sappan wood raw without any additional management and have high economic value, as well as other spices which are only used as raw materials for cooking in the kitchen. Therefore, the purpose of this service program is to provide information through counseling and training in processing sappanwood and spices into products that have high economic value and are close to existing standards. In addition, to increase production and help market access for processed wood products sappan and spices in the community to be wider. The benefit of this service program is that the people of Banjaragung Village can utilize the Secang wood and spices into products processes of high economic value into health tea products, so as to improve family welfare by increasing income, especially farmers in Banjaragung Village. Healthy tea which is rich in antioxidants, it is hoped that the level of public awareness in processing sappan wood and spices to consume it can be increased. Based on the explanation above, this community service program is expected to increase public insight and improve the economic level of the community in Banjaragung Village.

\section{Methode}

The place for the implementation of the Community Partnership Program is in Banjaragung Village, Rengel District, Regency, Tuban East Java Province. The distance from Banjaragung Village to Tuban Regency is $24 \mathrm{KM}$. The implementation time of this program is from June 2021 - September 2021. The target of implementing this partnership program is for Village Farmers and youth groups who are still not working in Banjaragung Village. The method applied in this Community Partnership Program is Society Participatory, the community as partners are able to absorb skills in the utilization and processing of sappan wood and spices into products of high economic value through by doing. In addition, it is a persuasive approach through counseling on the benefits of sappan wood and spices, thereby providing a stimulus for the community to use sappan wood and spices due to the health and economic benefits of utilizing and processing sappan wood. To the community these are:

1. Coaching is conceptualized with explanations and presentations from resource persons related to antioxidants and natural dyes from wood sappan and spices:

a. Knowing antioxidants, by knowing antioxidants and their benefits, people will gain more knowledge so they can change their mindset so that willing to process sappan wood into a product that has high economic value

b. Know the benefits contained in spices (red ginger, lemongrass, cinnamon, turmeric)

2. Direct training with the practice of making tea Health:

a. Getting to know the sappan wood plant and spices more in

b. Plant processing practices wood se nuts and spices intotea bags health that are easy to serve and consume

c. An overview of the health tea business 
3. Feedback/question-and-answer activities regarding spice plants found in the yards of local residents

4. Evaluation of the implementation of community service which includes:

a. Suitability of training activities with community needs

b. The purpose of this training activity is with the problems faced by the farming community in banjaragung village.

c. Competence of lecturers/students who bring training on the

d. Sustainability of service programs. Community.

\section{Results and Discussions}

The results that have been achieved in the Community Service Program implemented in Banjaragung Village, Rengel District, Tuban Regency are as follows:

1. Presentation Materials

Community service begins with the delivery of material as a stimulus or stimulus. Community Service participants are allowed to interact by asking questions, then the extension and workshop team on duty will provide answers to questions that arise. The material presented was about antioxidants and natural dyes as well as the benefits of each raw material used and continued with how to manufacture Health Tea beverage products. At the time of material presentation, raw materials and products that have been prepared previously from the laboratory are presented and distributed to participants, so that participants know the characteristics that will be produced at the end of this training. With the presentation of the material, it is hoped that it will open the participants' knowledge about the benefits of sappan wood and spices as a source of antioxidants and traditional medicines that are safe for consumption. In the presentation session, information was also given about the application of making Health Tea. The interest of these community service participants has started to be seen since the material presentation session and is increasingly visible during the practice of making products with the emergence of many questions from participants. After the presentation of the material, participants practice making Health. (a) Laboratory tests, (b) presentation of material to youth participants

(c) Practices of making Health Teas which are carried out alternately. From this training, participants also explained how to do the brewing and the amount of serving size is good for a cup of drink if it will be consumed
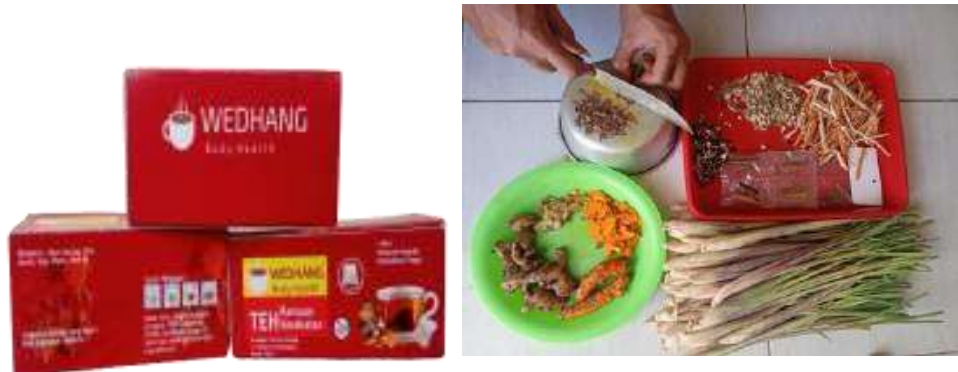

Figure 1. Health Tea Packaging, Community Service Practicum Results

\section{Practice of making Health Tea}

Secang wood and refined spices are put in tea bags and then wrapped in packaging hygienic containing 20 tea bags.

General Description of The Business Participants are given an overview starting from the production process to economic analysis. The following is an overview of the sappan wood powder business.

\section{The Idea of Business Activities}

Seeing Secang wood and spices in the Tuban area which is still lacking in utilization, the team took the initiative to use it into a contemporary product that is also liked by all people, namely tea bags, this type of product refers more to herbal drinks but is adopted as tea dip because of the increasing number of tea fans. In addition, this health tea is also expected to be an education for all circles of society, because this health tea is different from usual tea, this tea has many benefits for the health of the body, one of which is increasing immunity and overcoming stomach irritation. Therefore, an idea or a notion of a group of authors to make this community service. 


\section{Market Opportunities and Business Economic Analysis}

a. Market opportunities

Market Opportunities According to (Kotler, 2008) is a field buyer requirement where companies can operate profitably. In the unfinished condition of COVID-19, people need beverages and food products that can increase immunity. This situation is an opportunity for health tea products in marketing, because this product has advantages, one of which is that it can improve the immune system.

In addition to the above conditions, health tea is one type of beverage that is much sought after by consumers, especially health tea which is safe for consumption and has advantages in the realm of health. Health tea has advantages that tea enthusiasts need, therefore it can be concluded that Health Tea has a broad market opportunity and is in accordance with market needs.

b. Market Potential Analysis
1) Target market segments are:

2) Lower and upper middle income

3) Group Age group of youth and adults as well as elderly

c. Targeting (Main Target)

The group of people who like to consume tea are mostly young people.

1) Community groups who are looking for herbal medicinal drinks at affordable prices.

2) Positioning Consumers view theHealth Tea product. Reproductive This community service team is a creative, innovative product, different from others and the price is not expensive.

d. Business Economic

Profit analysis from the marketing of the "Health Tea" product is presented starting from the assumption of the equipment usage period, fixed costs, variable costs, operational costs, revenue costs, and profit per production. As follows:

Table 1. Initial Investment

\begin{tabular}{llll}
\hline Description & amount unit & Cost / unit (USD) & Sub Total (Rp) \\
\hline Blade & 5 & $\operatorname{Rp~5,000}$ & to $\operatorname{Rp~25,000}$ \\
Trays plastic & 5 & $\operatorname{Rp~3,500}$ & to $\operatorname{Rp~17,500~}$ \\
Tool Press plastic & 1 & $\operatorname{Rp~70,000}$ & to Rp 70,000 \\
\hline \multicolumn{2}{r}{} & & TOTAL $\$ 112,500$ \\
\hline
\end{tabular}

Table 2. Cost Depreciation in One Month

\begin{tabular}{ll}
\hline Tools That Used Production & Shrinkage (Rp) \\
\hline Knives & 300 \\
Plastic TraysPlastic & 200 \\
Press Tools & 6,500 \\
\hline Total Shrinkage & 7,000
\end{tabular}


Table 3. Raw Material Costs One TimeProduction

\begin{tabular}{cccl}
\hline Raw Material & Number of Unit & Costs $(\mathrm{Rp})$ & Sub Total (Rp) \\
\hline Secang Wood & $1 \mathrm{~kg}$ & 20,000 & 20,000 \\
Red Ginger & $1 \mathrm{~kg}$ & 14,000 & 14,000 \\
Lemongrass & $1 \mathrm{~kg}$ & 6,000 & 6,000 \\
Turmeric & $1 \mathrm{~kg}$ & 13,000 & 13,000 \\
Cinnamon & $100 \mathrm{gr}$ & 11,000 & 11,000 \\
Siwalan bark & $1 \mathrm{~kg}$ & 5,000 & 5,000 \\
\hline
\end{tabular}

Table 4. Supplementary Costs in One Production

\begin{tabular}{clcl}
\hline Description & Amount Unit & Cost/unit (Rp) & Sub Total (Rp) \\
\hline Teabags & 5 Boxes & 18,000 & 90,000 \\
Packaging & 25 Sheets A3 & - & 15,400 \\
\hline \multicolumn{2}{c}{ TOTAL } & & 105,400 \\
\hline
\end{tabular}

Table 5. Total Cost

\begin{tabular}{ccc}
\hline Costs Production & Costs Total Costs (Rp) \\
\hline Costs Raw Material & Variable & 69.000 \\
CostsAuxiliary & 105,400 \\
& CostsFixed Costs & \\
Depreciation & 7,000 \\
\hline TOTAL & 181,400 \\
\hline Information & Amount (Rp) \\
\hline Total Receipt & 325,000 \\
Total Cost & 181,400 \\
\hline R/C & 1.79 \\
\hline
\end{tabular}

Table 6. Total Production Revenue

\begin{tabular}{cc}
\hline Remarks & Total \\
\hline Production & 25 Pcs \\
Price & Rp 13,000 \\
\hline TOTAL REVENUE & Rp 325,000 \\
\hline
\end{tabular}


Analysis Revenue Cost Ratio

It can be concluded that in one production, Health Tea gets a profit of Rp. 143,600,-, and shows that this business has a Ratio/Cost of 1.79 hich indicates that this business is not losing.

\section{Evaluation}

Overall, the event went well, smoothly and received a positive response from the participants of this counseling. This can be seen in the results of the questionnaire distributed after the completion of community service. Based on the results of the evaluation, it appears that the Community Service participants gave a good response to the activities carried out. As many as $89 \%$ of participants have never participated in Community Service with similar topics and around $94 \%$ stated that the topics presented were interesting and added insight. Participants also felt that this Community Service activity was useful for them, the extension workers provided good information and the media used was very easy to understand. The results of this questionnaire indicate that this activity in the form of counseling and short training can be carried out again in the future. Most participants $(88 \%)$ wanted to try and pass this information on to others. Several negative responses will be used as evaluation material for the Community Service implementation team.

\section{Conclusion}

Community service activities in Banjaragung Village with the title "Community Empowerment with Training on Making Spice Tea Bags in Banjaragung Village, Tuban Regency" have been carried out properly in accordance with the planning that has been carried out. Making health tea bags and questions and answers. The enthusiasm and active participation of the participants greatly support the sustainability of this program. It is hoped that with this community service activity, participants can see the potential of sappan wood and other spices to be applied in various food products that can help improve the economy of community service participants.

\section{Refrences}

Anonim. 2020. Covid-19 Distribution Health Office in Tuban Https://In.tuban.go.id/covid19, accessed on 20 August 2021.

Artiningsih, A. Purwaningtyas, E. 2016. Development of optimizing the extraction of purple anthocyanin from siwalan fruit peel and implemented as a natural dye on fabric cotton. Proceedings SNST,44-5.

Ernawati L. 2019. Healthy Living With TOGA (Family Medicinal Plants). Like:Yogyakarta.

Kartasapoetra, G., 2004, Cultivation of Medicinal Plants, Rineka Cipta, Jakarta.

Kusmiati, Dameria, \& Priadi, D. 2014. Analysis of Active Compounds of Secang Wood Extract (Caesalpinia Sappan L.) With Potential Antimicrobial. National Seminar on Green Industrial Technology 1. Pg. 169-174.

Puji, A. 2021. Benefits of Secang wood. URL: https://hellosehat.com/herbalalternative/herbal/benefits-kayusecang/ Accessed February 12021.

Rina, O., Utami, C., \& Ansori. 2012. Effectiveness of Extraction of Secang (Caesalpinia Sappan .L) As Eat Preservative. Journal of Applied Agricultural Research, 2(3), 181186.

Widowati, W. 2011. Phytochemical and Antioxidant Potential Test of Ethanol Extract of Secang Wood (Caesalpinia Sappan L.). Journal of Public Health. 11(1):23-3. 